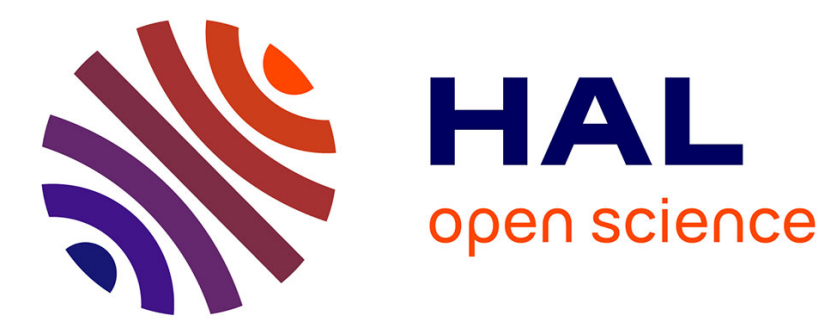

\title{
Borders vs. networks in eastern central Europe Violette Rey
}

\section{To cite this version:}

Violette Rey. Borders vs. networks in eastern central Europe. Flux - Cahiers scientifiques internationaux Réseaux et territoires, 1991, 7 (3), pp.21-28. 10.3406/flux.1991.1145 . hal-02885546

\section{HAL Id: hal-02885546 https://hal.science/hal-02885546}

Submitted on 30 Jun 2020

HAL is a multi-disciplinary open access archive for the deposit and dissemination of scientific research documents, whether they are published or not. The documents may come from teaching and research institutions in France or abroad, or from public or private research centers.
L'archive ouverte pluridisciplinaire HAL, est destinée au dépôt et à la diffusion de documents scientifiques de niveau recherche, publiés ou non, émanant des établissements d'enseignement et de recherche français ou étrangers, des laboratoires publics ou privés. 


\section{Borders vs. networks in eastern central Europe}

Violette Rey, Judith Crews

\section{Citer ce document / Cite this document :}

Rey Violette, Crews Judith. Borders vs. networks in eastern central Europe. In: Flux, n³, 1991. pp. 21-28;

doi : https://doi.org/10.3406/flux.1991.1145

https://www.persee.fr/doc/flux_1154-2721_1991_num_7_3_1145

Fichier pdf généré le 12/05/2018 


\title{
BORDERS VS. NETWORKS
}

\section{IN EASTERN CENTRAL EUROPE}

\author{
by VIOLETTE REY
}

Violette REY, agrégée and Docteur d'Ftat, is professor of geography at the Ecole Normale Supérieure at Iontenay-St. Cloud and at the University of Paris $I$.

Her researcb concerns regional organization and territorial systems. She has specialized in eastern Central Europe, and is the autbor of several works on Rumania and Eastern Europe. She is also working on French rural space.
The events of 1989 in Eastern Europe force us to ask questions. The opening of national boundaries and feelings after forty years of almost hermetic closure has sent shockwaves throughout all of Europe. W'hat was the role played by networks in all these events? What will it be in the future? For the moment, there is no answer, particularly as concerns those secret, personal networks connecting Moscow, New York, (Malta), and Berlin.

Immutability gives us as many reasons to ask questions. There is hardly another space in the world which resembles eastern Central Europe: so many scams, fractures, and other boundaries - some as old as time, others ephemeral. Eastern Central Europe is a veritable laboratory for reflecting on the articulations between "boundary-effects" and "network-effects": but a strange laboratory, where it is a known fact that the claboration of state-controlled territoriality has always been particularly difficult, and where a kind of defiance of modelization exists which appears as the expression of a lasting phenomenon

At a moment in history when renewed energy is permitting flow with contiguous Western Europe and the rest of the world to be re-established, as networks join back together again, this article will try to explain the recurrent complexity of territorial construction in the geographical space of castern Central Europe.

\section{THE CLOSING OF THE BORDERS AND SOCIALIST SPATIAL MARKING}

The period of time from 1945.1\%)( which suddenly seems so brief, saw the setting up of an castern European space with specifically socialist markings. This construction made use of the three classical methods for spatial development. 
namely, action on networks, nodes and links. Our question here concerns the specific role of networks, and how they were articulated within the links and nodes.

As we begin it would be useful to recall the projects and principles upon which socialist space was intentionally and determinedly founded. This space was the result of a phase of geostrategic conquest and Soviet military advancement. Priority was moreover given to actions of spatial control, stationing, and flow-supervision. The boundary of the system (the Iron Curtain) was its key element. It fragmented territories which had been constituted upon other bases: divided Germany, and a Poland translated towards the West are just two major examples. This voluntary construction of eastern European space was also the product of an ideological project: namely, the building of a socialist society fashioned on the pre-cxisting Soviet model. This was to result in a new set of relationships (social, economical, spatial, and so on), seen as the product of equality among elements: an equality controlled and guaranteed by the elite of the working class erected into the Party. Strategic needs and social construction from above combined to make the spatial procedures of hicrarchical allotments outweigh the spatial procedures of mobility across networks.

We shall proceed with a spatial reading of this combination on two levels, first in the overall socialist space, and then in the internal space of each State.

For socialist space, the anchor-point to the East, and the central administrative supervision, that is, Moscow, resulted in the appearance of a particular type of network, completely out of balance with the structures in place prior to 1945 (Figure 1). Air traffic routes, railroads, subways and even some of the major highway axes all came under the sign of Sovict polarity. The arteries of priority traffic now became east-west in orientation; their strategic functions were no different from their economic functions; and the only ones to use them were merchandise, troops... and chicfs!

The attachment to the East was also obvious in the application, within each State, of the same principles of organization of territory concerning

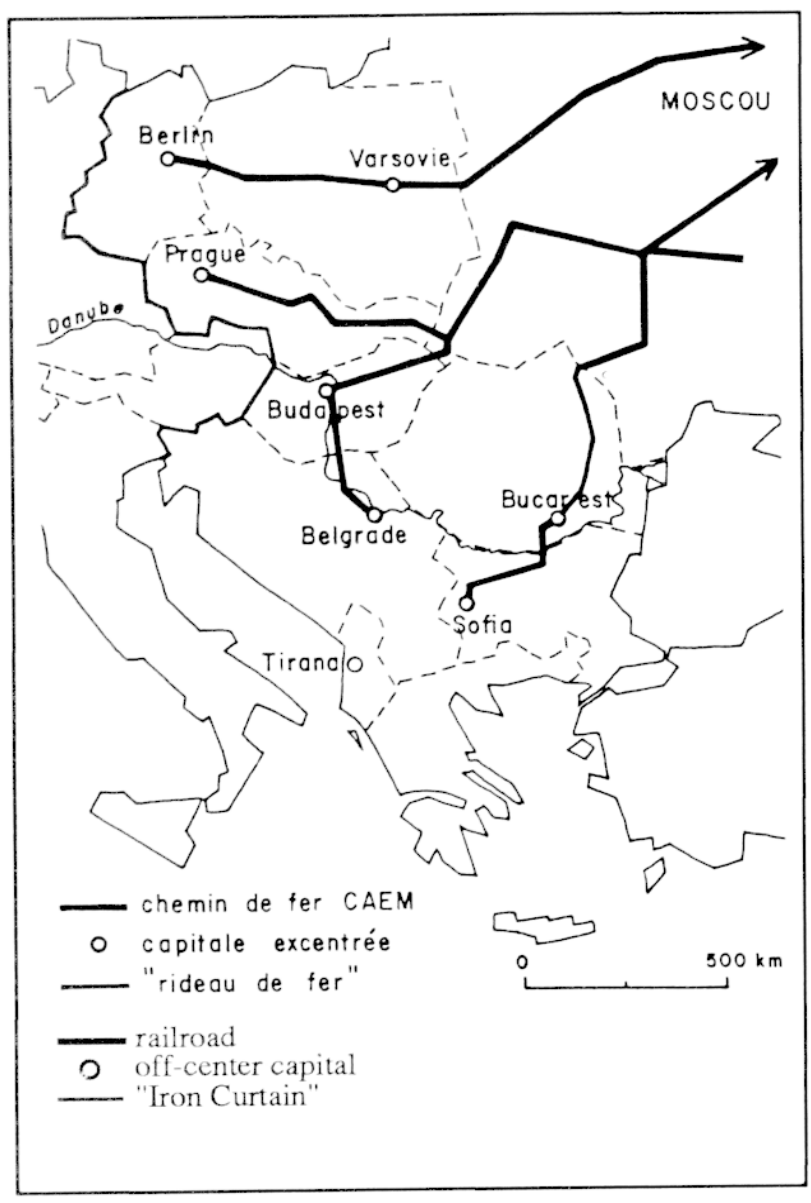

FIGURE 1: ATTACHMENT TO THE EAST THE GEOSTRATEGIC RAILWAY SYSTEM

administrative intermeshing, the place of the capital city, and the function of the national borders. Administrative meshes are not networks, and yet their role here cannot be excluded, because they determined the number and relative importance of the major urban centers, which in the economics of total command is essential. Now, what really took place? Through a series of remodelings, a structure like that of the French Département was established, which turned out to be more or less regular and similar from one country to the next, and which thus partook of territorial construction of the most general kind; above all, there was a determining effect on the specific urban growth of most of the administrative towns. It was these average-sized towns which received the largest share of housing investments, the basis for recent urban growth, and, during a very brief lapse of time (the 60 's and 70's), there was a surprising regularization of the urban networks, on the basis of uniform distribution, which benefitted mid-sized urban 
areas: towns with a population between $50-150,000$ inhabitants. At the top of spatial organization, the accentuation of the central position of the capital city was marked on certain traffic networks, even if in total numbers of inhabitants, the demographic concentration of the capital city remained relatively unchanged. For example, all that remains of the Rumanian air traffic routes interconnecting the regional metropolises until the mid-1970s is an elementary radial network centered in Bucharest (Figure 2). On the outer edges of this state-controlled space, the national borders became mere separations between two neighbor countries. Transit areas were few and far between; and any flow, chiefly of merchandise, became carefully channeled. Thus impermeable borders were imposed, to be increasingly strengthened over the years with the various political events in one or another of the countries. They traced a network of invisible walls on either side of which highways simply ended in small towns which somehow resembled the end of the road. In places the highways run only parallel to the borders, not across them, and in general, there is a mobility problem with the border regions in these countries, which have become zones subjected to the stress of depopulation, enclosure, economic standstill and lack of equipment. The exceptions are the few transit/transfer points on the Soviet border.

In light of this spatial structuration, which is itself directly connected to the determination for hierarchical control and an ideology of spatial homogenization and uniformity, what do the marks of economic activity, and in particularly the circulation networks which are its nervous system, represent?

The socialist economy of the Soviet type, often referred to as a "centrally planned economy", gives more conceptual, doctrinal (and practical) priority to activities producing material goods than to activities concerned with communications and services. Services, because they are not expressed in terms of the production of objects, thus become invisible, vague and completely suspicious. From this rather elementary value hierarchy ensues the insufficiency and deficiency of all the transportation and communication systems. Without this doctrinal reference it would be impossible to otherwise understand the paradox of the weakness of transportation in a system of totally planned out, centra- lized state control. Almost everywhere on the globe, transportation infrastructures are the very type of equipment which is either piloted by the State, semi-public, or a complete state monopoly due to the high capital outlay and spatial require. ments, and since they provide multiple utilizations.

But there is more than one paradox here. The question is one of a functional contradiction at the base, which, by a cumulative effect over the course of time, must bear the burden in the general collapse finally brought about by the events at the end of 1989. This functional contradiction is based on an opposition between production and transportation. On the one hand, the larger, and even the largest, specialized production units (industrial complexes, collective farms), require large inputs and outflows; and on the other, the transportation networks were set up afterwards rather than prior to the productive equipment itself. They were insufficient, incomplete and incapable of corresponding to the spatial structure of production. Every day there are reports about the scope of the backlog accumulating in everything concerning the material support for exchange and circulation. Dangerously antiquated railways (only a few have even been electrified); the absence of highway transportation for goods due to the lack of an adequate road networks; archaic telecommunications.... Only at the price of a high priority investment in these areas could diversified economic growth begin to be envisaged, in which foreign firms would be willing to risk investments.

To conclude this initial approach to the relationship between territory and network in Eastern Europe during the socialist phase, it should be kept in mind that the extreme weight of the model of absolute hierarchical centralization is spatially demonstrated at the nodes - major and relay centers - and on the limits of the territorial envelope, much more so than in the networks themselves. Through a kind of formal homology, the abstract lines of the porders trace out a network on the maps, nets within nets which surround and confine closed spaces, and which are, in fact, an anti-network. It was as if there had been a determination to create a new kind of territoriality inside the borders, but the result was simply a different kind of territoriality based on rupture rather than on exchange, where exclusion won out 
FLUX 3 Spring 1991

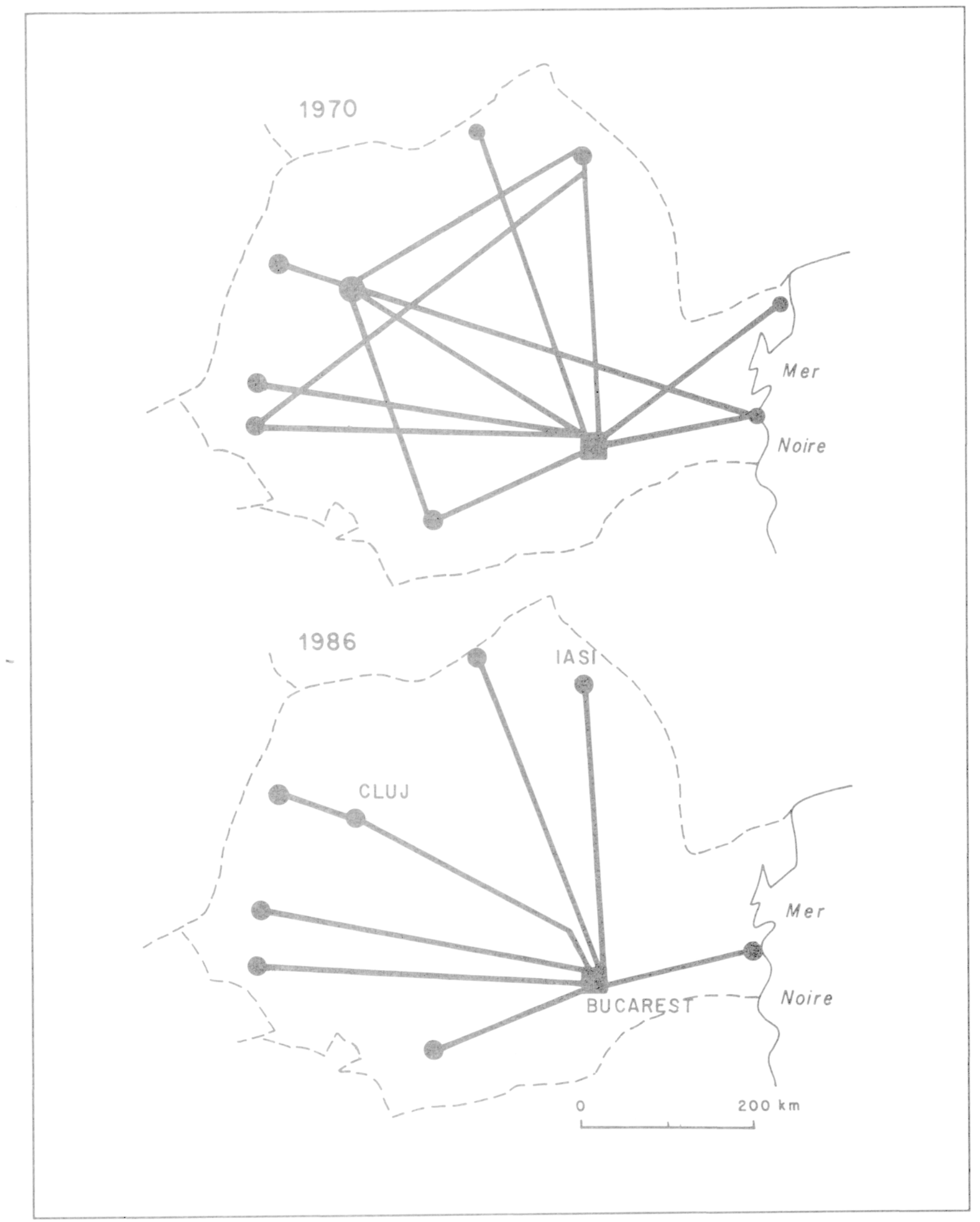

FIGLRE: 2: THE POWTER OF CENTRALIZFD AUTHORITY AIR TRAFFIC ROUTES I. RI MANIA, 1970 and 1986

24 
over contact... and in which non-information became the rule. Will these spatial markings disappear in the probable re-anchoring of this space toward the West? The long history of this part of Europe would seem to indicate rather to what extent constructed space is able to resist social and political change.

\section{A LONG HISTORY OF DISCONNECTED NETWORKS}

The geopolitical concept of Eastern Europe is on its deathbed, if not already dead and buried. What remains is the historical and geographical concept of eastern Central Europe.

Historically, this concept records a temporal bifurcation at the beginning of the modern era, as the West consolidated into nation-states and developed a mercantile and Atlantic-oriented economy. The center of Europe tended, instead, to look for its structures toward the East, renewing the institution of scrfdom and forming into large multi-ethnic empires. Geographically, this concept defines the intermediary space of semi-continentality between the fragmented extremity of the peninsula, and the immense horizons of the Russian steppes, which became a space of nation-states at a relatively late date (end of the 19th century, and after the treaties of 1919.1920).

Two questions related to the "border-network" debate might be raised concerning long duration in this region. First, does a territoriality specific to eastern Central Europe exist at all? Secondly, to what extent does the heterogeneity of the inherited networks limit more than it stimulates the construction of new national territories?

In answer to the first question, let us begin by stating that by "territoriality" a particular mode of relationship between a society and its space must be understood. That is, a particular society lays out its area in a distinctive manner, and these places become so many signs and messages about the society itself, its culture, and its specific and autonomous identity.

Territoriality in this part of Europe is a complex and very tricky matter. Throughout the singular history of settlement here, the density and imbrication of national groups has forced peoples with different territorial experiences to live together in the same space. Comparisons of the form and organization of space in German-type vs. Slavic type villages is practically a text-book excrcise. But it is a recurring surprise to actually see the permanence of these differences on each subsequent visit the region. The social division of functions, an expression of the peculiarities of cohabitation, with their corresponding spatial division, was taken over by different national groups. For example, the Germans established an "archipelago" of cities as early as the 13th century, where technological know-how freely circulated. The Jews organized commercial life and furnished the major impetus for urban growth at the end of the 19th century from the borders of Galicia to Moldavia; this urban distribution collapsed for a time with the elimination of the Jews.

These peculiarities of fragmentations and cohabitation connote the feclings of territoriality. Each group - with its particular consciousness of "group", efforts to preserve identity and "being" - often expresses its territoriality through aggressivity and the need to close in upon itself, to protect itself from the others... because it is lacking in self-assurance and the security of its identity. Territorial experience is first of all a local experience, articulated on closed, internal networks (marriage between groups, for example) and/or upon the international networks of distant relays which are nevertheless in liaison with the group (phenomenon of diaspora). Because of this, there is a certain malaise in thinking of oneself inside a space as large as the State, because one must keep inventing signs which pertain more to cohabitation than to exclusion. Such was the challenge of the constructions of the state-controlled territories which resulted after the First World War, and which were re-designed in 1945.

Behind the brand-new national-boundary envelopes, the new States were supposed to solve the problem of creating a certain centrality acceptable to the entire population, and at the same time set up interrelations which would infuse and link together all the different regions - a double difficulty in the extreme, to say the least. 
On the one hand the capital cities were almost all eccentric with respect to the territory they represented: Prague, Budapest, Bucarest, Belgrade and Sofia are all off-center. It was difficult to establish the model of radial-designed circulation centered in the capital and radiating out into national space; it was achieved only at the price of a complete deformation of the networks themselves. On the other hand, in nearly every case, the national territory bears the marks of the clash between two concepts of networks and two concepts of territorial framework, coinciding with the border line of the former Empire of the Hapsburg monarchy, crossing Yugoslavia, Rumania, Czechoslovakia and which was extended, in signification if not in reality, by the line between Prussia and the Russian Empire on Polish territory. To the West, a circulation network symbolized by the railroad: the end of the 19th century saw the multiplication of the railroads, which were considered the essential mark of modernization, and nearly the sole investment for Western capital. The famous map of the state of the railways in Europe in 1914 is an indirect image of the boundaries of the Empires of Mittel Europa: on the near side, a reticulated, very dense network, and on the far side, the lines which have penetrated the borders, among them the famous Orient Express and the Berlin-Warsaw-Moscow (see Figure 3).

It would be inexact to draw the conclusion of a simple effect of unequal degree of development in viewing this railroad network, initially a symbol of modernity. A network has meaning only in relationship to something else. Now, in the West, circulation networks were connected and juxtaposed on the urban structure, wheras to the East, there is dissociation and disconnection between the two systems. The Czarist Empire built an imperial network with strategic control as the object; the priority was to attain the limits of the Empire, by means of direct traffic axes which were not to $\mathrm{mix}$ with local traffic. Viewed from within, on a large scale, this dissociation becomes very obvious when the housing and settlement structures, regional circulation, and general circulation networks are observed. This dissociation, which originated as the networks were being set up, and not due to functional specialization in traffic-flow, siginifies and maintains a type of territoriality fragmented into spaces of relationships which are foreign to each other, with no interconnection. In the Balkans, formerly under the control or influence of the Ottoman empire, a very similar disconnection can be observed between places where people live, and the highwaynetwork, which until very recently was used only by troops, princes, and tax collectors - a network thus synonymous with centralized power, and always distant and foreign.

This deeply-etched heritage of different modes of habitation and communication still weighs considerably on both sides of the now-vanished boundaries, which nonetheless still continue to "exist" in the structuration and functioning of contemporary national spaces.

The case of Poland is a good illustration of the delicate cohabitation of old territories which must be integrated as part of new national space. We know that the present-day boundaries, as much to the east as to the west, date from the Second World War. One might imagine that former borders have disappeared, but, in fact, nothing of the sort has occured. This is exactly what comes out in analyses undertaken by Polish geographers, and this in spite of all the efforts of the authories since 1945 to homogenize the territory. On the one hand, the highway network, which is the basis for bus transportation for commuters and travellers, appears as a finely-reticulated and regular network. In contrast, the railway system still demonstrates the dissymetry on either side of the former boundary between the two empires (Prussia and Russia) which constituted itself as the "front", after having wiped the Polish state off the political map of Europe at the end of the 18th century.

Finally, if we analyze a huge collection of spatial phenomena, those linked to demographic behavior as well as to degree of equipment and forms of activity, a third noticeable rupture becomes apparent, namely, that between western German space until 1945, and all the rest. Thus, a cutting into three bands on a north-south orientation, with an effect which is restricting in a different way from the physical division, east-west, runs from the Carpathians to the Baltic sea. This banding brings out a central section in which are concentrated at the present time the best conditions for different activities. This central band corresponds to the lands which were under Prussian control between the 
A comparison of territory on either side of the 1796-1918 border between the Russian, Prussian and Hapsburg empires clearly shows a dense and reticulated 19th-century network to the West, and a recent, linear network to the East.

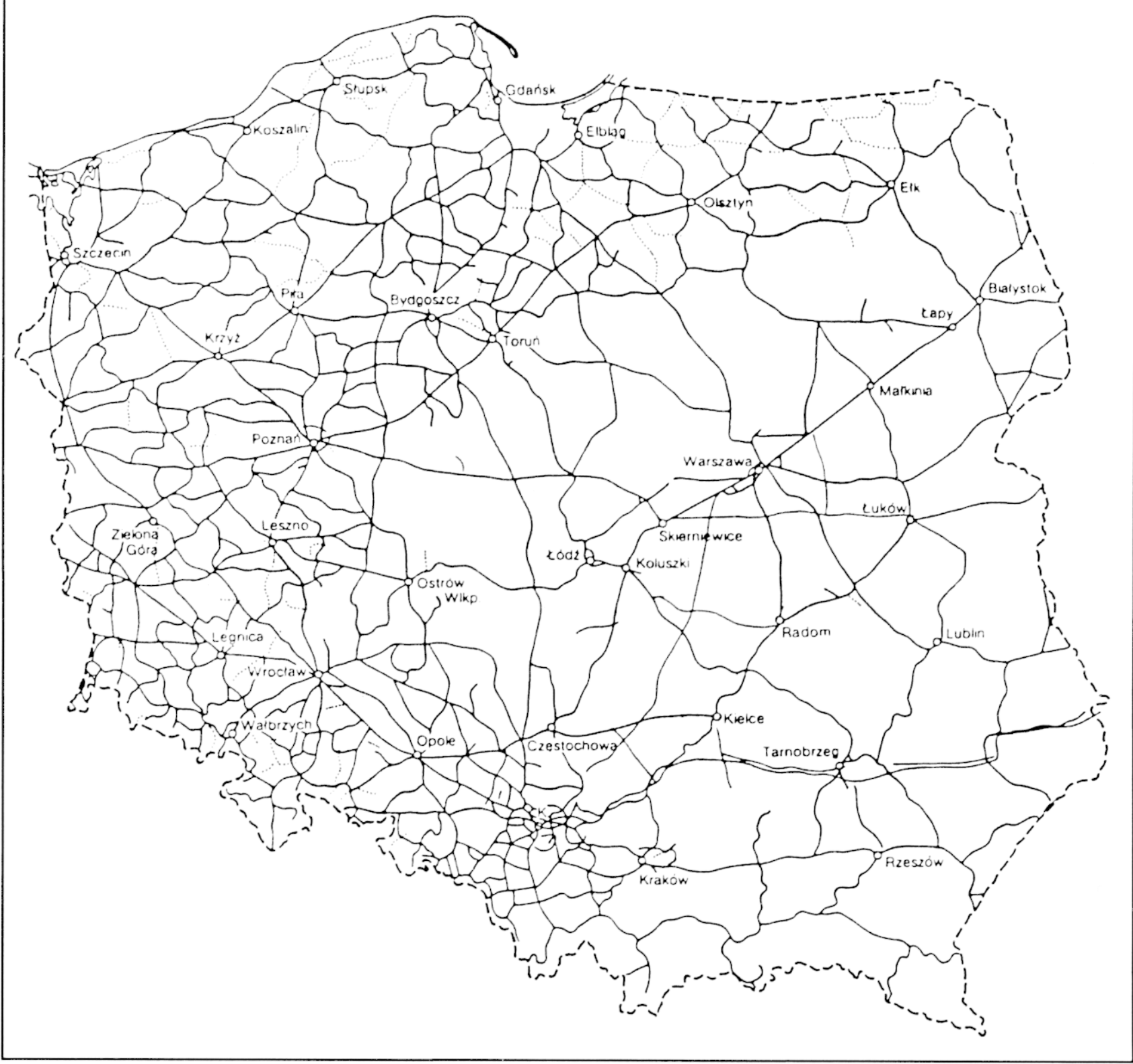

FIGURE 3: HISTORIC BOUNDARIES AND THE LIMITS OF NETWORKS THE POLISH RAILWAY SYSTEM

end of the 18th century and 1918 , but which were Polish before that. At the root of this better relative position there is, precisely, the articulation of every category of network, from village water systems for better hygiene, and dense highway networks between compact villages, all the way up to a large national traffic network. The principal artery of
North-South traffic passes here, between industrial Upper Silesia to the port of Gdansk, an extremely powerful axis, a kind of vertebral column which the more eastern axis of the Vistula through Warsaw, and a constant source of worry which its administrators cannot quite seem to get rid of. 


\section{FLUX 3 Spring 1991}

What ought we to conclude? Once again, there is confirmation of the inexhaustible differential efficiency of spatial structures, according to whether they are founded on networks which are multiple and connected, combining "natural, spontaneous networks" with "experimental networks", or whether they are simply founded on elementary and uncoordinated networks. In this sense, we can speak of a spirit which is proper to each system of network. From a methodological point of view, it is thus very useful to keep in mind the distinction between the two types of network: those which are more or less natural and spontaneous, whose hierarchization is the result of ascending organi- zation; and those anticipated from above, built according to descending hierarchy, with a less certain capacity for mobilizing local energies.

Finally, the memory of an area remains terribly well written into its networks, which makes the transgression of networks infinitely more difficult to operate than the transgression of boundaries. We can see how this remanence, this hysteresis of networks can enlighten in an entirely different fashion the tragic projects of systematization of networks of habitation...

(translated by J. Crews)

\section{REFERFNCES}

LIJEWSKIEGO, T., 1985. "Uklady komunikacyjne wojewordztur," ("Reseaux de communications au niveau des voivodies"), 8 Cartes, NAUK, Varsovie.

RAFFESTIN, C., 1988. "Repères pour une théorie de la territorialité humaine." In Réseaux territoriaux. Paris: Paradigm.

REY, V., 1989. "Les marquages du pouvoir des états dans l'Europe de l'est: le phénomène de la frontière." In Régions et pouvoirs régionaux en Eumope de l'Est et en URSS, ed. Radvany and Rey, pp. 11-21. Paris: Masson.

RITTER and HAJDU, 1988. "The east-west German boundary." Gengraphical Review, pp. 326-344. 